\title{
Preserving Ultra-Pure Uranium-233
}

\section{September 2011}

Prepared by

Alan M. Krichinsky

Global Nuclear Security Technology Division

Oak Ridge National Laboratory

Steve A. Goldberg

Office of the Director

New Brunswick Laboratory

Ian D. Hutcheon

Glenn Seaborg Institute

Lawrence Livermore National Laboratory

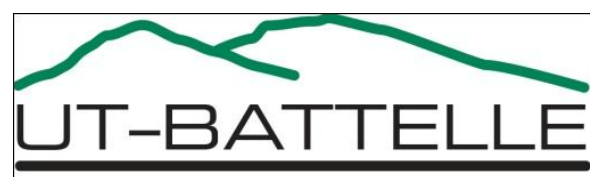

OAK RIDGE NATIONAL LABORATORY

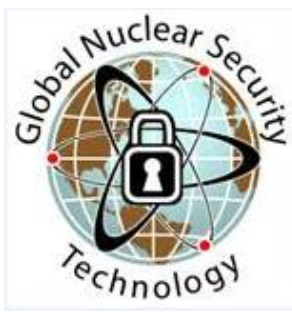




\section{DOCUMENT AVAILABILITY}

Reports produced after January 1, 1996, are generally available free via the U.S. Department of Energy (DOE) Information Bridge.

Web site http://www.osti.gov/bridge

Reports produced before January 1,1996, may be purchased by members of the public from the following source.

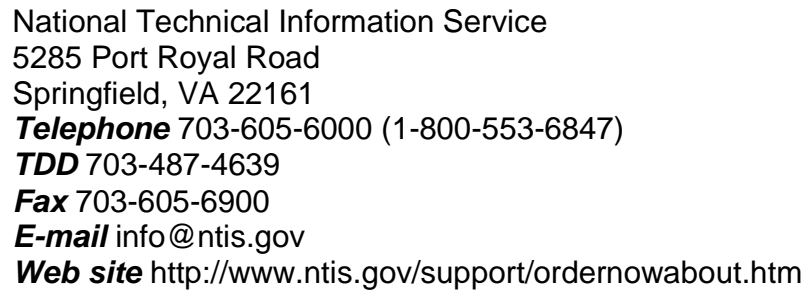

Reports are available to DOE employees, DOE contractors, Energy Technology Data Exchange (ETDE) representatives, and International Nuclear Information System (INIS) representatives from the following source.

Office of Scientific and Technical Information

P.O. Box 62

Oak Ridge, TN 37831

Telephone 865-576-8401

Fax 865-576-5728

E-mail reports@osti.gov

Web site http://www.osti.gov/contact.html

This report was prepared as an account of work sponsored by an agency of the United States Government. Neither the United States Government nor any agency thereof, nor any of their employees, makes any warranty, express or implied, or assumes any legal liability or responsibility for the accuracy, completeness, or usefulness of any information, apparatus, product, or process disclosed, or represents that its use would not infringe privately owned rights. Reference herein to any specific commercial product, process, or service by trade name, trademark, manufacturer, or otherwise, does not necessarily constitute or imply its endorsement, recommendation, or favoring by the United States Government or any agency thereof. The views and opinions of authors expressed herein do not necessarily state or reflect those of the United States Government or any agency thereof. 
Global Nuclear Security Technology Division Safeguards and Security Technology Group

\title{
Preserving Ultra-Pure Uranium-233
}

\author{
Alan M. Krichinsky \\ Steve A. Goldberg* \\ Ian D. Hutcheon**
}

Date published: September 2011

*New Brunswick Laboratory

**Lawrence Livermore National Laboratory

Prepared by

Oak Ridge National Laboratory

Oak Ridge, Tennessee 37831-6283

managed by

UT-BATTELLE, LLC

for the

U.S. Department of Energy

Under contract DE-AC05-00OR22725 



\section{TABLE OF CONTENTS}

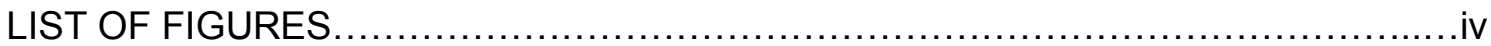

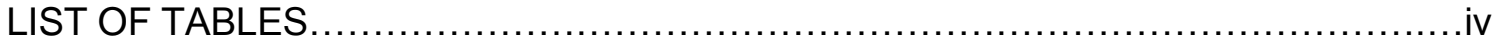

EXECUTIVE SUMMARY

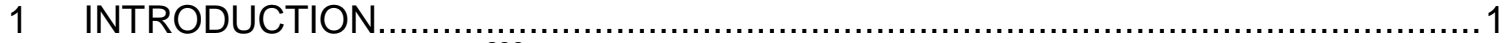

2 STUDY OF CURRENT ${ }^{233}$ U SUPPLY AND FUTURE NEEDS $\ldots \ldots \ldots \ldots \ldots \ldots \ldots \ldots \ldots \ldots$

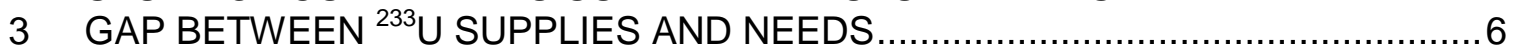

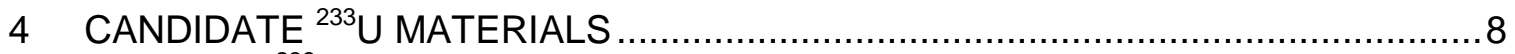

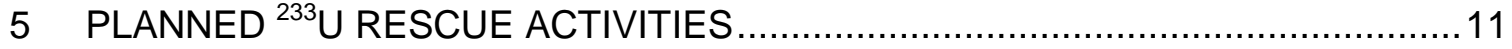

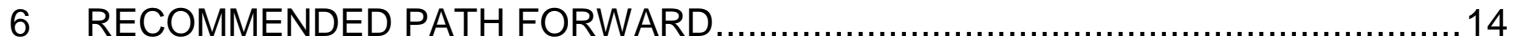

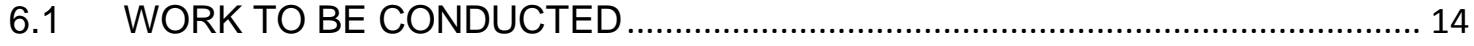

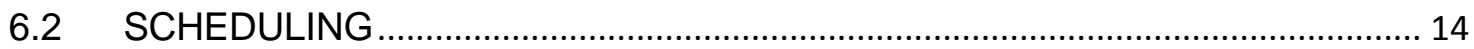

6.3 LOCATIONS FOR RETAINING PRESERVED ${ }^{233}$ U........................................... 15

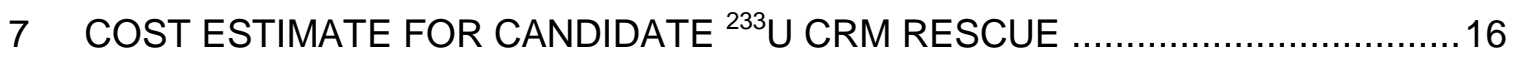

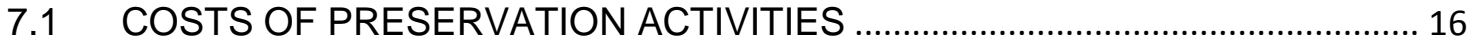

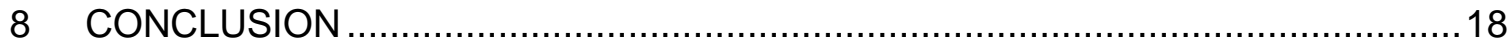

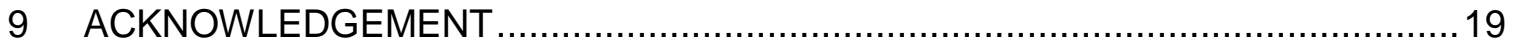

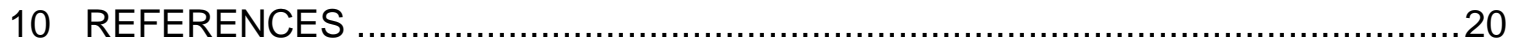




\section{LIST OF FIGURES}

Figure

Page

Fig. 1. Generation of uranium-233 from thorium-232. 1

Fig. 2. Cutaway drawing of cells, tube vaults, and some of the equipment .............2

Fig. 3. Selected package configurations for ${ }^{233} \mathrm{U}$ stored at ORNL

\section{LIST OF TABLES}

Table

Page

Table 1. Summary list of candidate ${ }^{233} \mathrm{U}$ materials .........................................

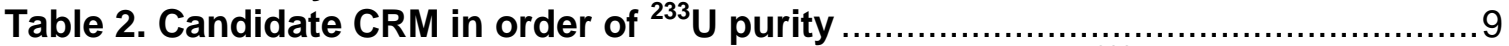

Table 3. Annualized estimate of costs for recuing candidate ${ }^{233} \mathrm{U}$ CRM ...............16 



\title{
Preserving Ultra-Pure Uranium-233
}

\author{
Alan M. Krichinsky, Oak Ridge National Laboratory \\ Steve A. Goldberg, New Brunswick Laboratory \\ Ian D. Hutcheon, Lawrence Livermore National Laboratory
}

\section{EXECUTIVE SUMMARY}

Uranium-233 $\left({ }^{233} \mathrm{U}\right)$ is a synthetic isotope of uranium formed under reactor conditions during neutron capture by natural thorium $\left({ }^{232} \mathrm{Th}\right)$. At high purities, this synthetic isotope serves as a crucial reference material for accurately quantifying and characterizing uranium-bearing materials' assays and isotopic distributions for domestic and international nuclear safeguards. Separated, high purity ${ }^{233} \mathrm{U}$ is stored in vaults at Oak Ridge National Laboratory (ORNL). These materials represent a broad spectrum of ${ }^{233} \mathrm{U}$ from the standpoint of isotopic purity - the purest being crucial for precise analyses in safeguarding uranium.

All ${ }^{233} \mathrm{U}$ at ORNL is currently scheduled to be disposed of by down-blending with depleted uranium beginning in 2015. This will reduce safety concerns and security costs associated with storage. Down-blending this material will permanently destroy its potential value as a certified reference material for use in uranium analyses. Furthermore, no credible options exist for replacing ${ }^{233} U$ due to the lack of operating production capability and the high cost of restarting currently shut down capabilities.

A study was commissioned to determine the need for preserving high-purity ${ }^{233} \mathrm{U}$. This study looked at the current supply and the historical and continuing domestic need for this crucial isotope. It examined the gap in supplies and uses to meet domestic needs and extrapolated them in the context of international safeguards and security activitiessuperimposed on the recognition that existing supplies are being depleted while candidate replacement material is being prepared for disposal. This study found that the total worldwide need by this projection is at least $850 \mathrm{~g}$ of certified ${ }^{233} \mathrm{U}$ reference material over the next 50 years. This amount also includes a strategic reserve. To meet this need, 18 individual items totaling $959 \mathrm{~g}$ of ${ }^{233} \mathrm{U}$ were identified as candidates for establishing a lasting supply of certified reference materials (CRM), all having an isotopic purity of at least $99.4 \%{ }^{233} \mathrm{U}$ and including materials up to $99.996 \%$ purity.

Current plans include rescuing the purest ${ }^{233} \mathrm{U}$ materials during a 3-year project beginning in FY 2012 in three phases involving preparations, handling preserved materials, and cleanup. The first year will involve preparations for handling the rescued material for sampling, analysis, distribution, and storage. Such preparations involve modifying or developing work control documents and physical preparations in the laboratory, which include preparing space for new material-handling equipment and procuring and (in some cases) refurbishing equipment needed for handling ${ }^{233} \mathrm{U}$ or qualifying candidate CRM. Once preparations are complete, an evaluation of readiness will be conducted by independent reviewers to verify that the equipment, work controls, and personnel are ready for operations involving handling radioactive materials with nuclear criticality safety as well as radiological control requirements. 
The material-handling phase will begin in FY 2013 and be completed early in FY 2014 , as currently scheduled. Material handling involves retrieving candidate CRM items from the ORNL storage facility and shipping them to another laboratory at ORNL; receiving and handling rescued items at the laboratory (including any needed initial processing, acquisition and analysis of samples from each item, and preparation for shipment); and shipping bulk material to destination labs or to a yet-to-be-designated storage location. There are seven groups of ${ }^{233} \mathrm{U}$ identified for handling based on isotopic purity that require the utmost care to prevent cross-contamination.

The last phase, cleanup, also will be completed in 2014. It involves cleaning and removing the equipment and material-handling boxes and characterizing, documenting, and disposing of waste.

As part of initial planning, the cost of rescuing candidate ${ }^{233} U$ items was estimated roughly. The annualized costs were found to be $\$ 1,228 \mathrm{~K}$ in FY 2012, $\$ 1,375 \mathrm{~K}$ in FY 2013, and $\$ 1,030 \mathrm{~K}$ in FY 2014. These costs correlate with the activities mentioned in the three previous paragraphs.

This report outlines a recent effort to assess the annual consumption of ${ }^{233} U$ in the United States, the gap between current supplies and future needs, and the initial planning for a program to rescue the purest of ${ }^{233} \mathrm{U}$ materials from destruction by downblending so they may be preserved for use as a crucial reference for safeguarding nuclear material. 


\section{INTRODUCTION}

Uranium-233 is a synthetic isotope of uranium typically formed under reactor conditions during neutron capture by natural thorium $\left({ }^{232} \mathrm{Th}\right.$; see Fig. 1).

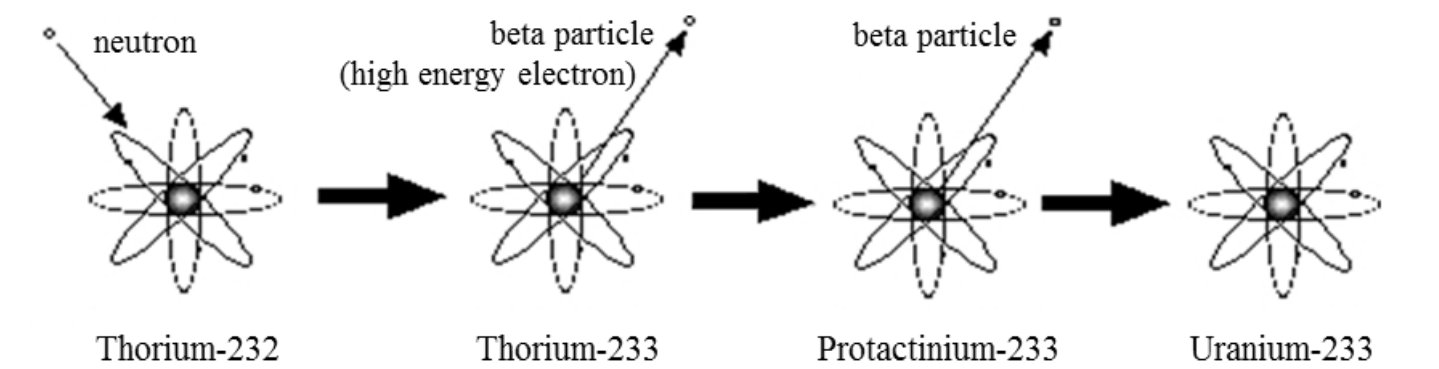

Fig. 1. Generation of uranium-233 from thorium-232

Although ${ }^{233} \mathrm{U}$ is chemically identical to the uranium-235 isotope $\left({ }^{235} \mathrm{U}\right),{ }^{233} \mathrm{U}$ is a fissile material that has some nuclear properties that are closer to plutonium-239 $\left({ }^{239} \mathrm{Pu}\right)$ than to ${ }^{235} \mathrm{U}$. Most notably, the subcritical limit for the mass of fissile nuclide in nitrate form is $0.78 \mathrm{~kg}$ for ${ }^{235} \mathrm{U}, 0.55 \mathrm{~kg}$ for ${ }^{233} \mathrm{U}$, and $0.48 \mathrm{~kg}$ for ${ }^{239} \mathrm{Pu}$. ${ }^{1}$ High-isotopic-purity ${ }^{233} \mathrm{U}$ also is weapons-useable; therefore, it requires extensive, very expensive security measures to safeguard it from misuse.

The national repository for separated ${ }^{233} U^{*}$ is located in Building 3019A at Oak Ridge National Laboratory (ORNL). Building 3019A is the oldest operating nuclear facility in the world, and was the site of the first separation of plutonium in gram quantities from spent reactor fuel. It also was the site of the first pilot-scale demonstrations of the PUREX solvent extraction process, which has developed into the standard flowsheet for processing spent reactor fuel for over half a century. ${ }^{2}$

At its heart, the facility has seven concrete-shielded, remote processing cells. These cells provide the foundation for tube vaults in which the ${ }^{233} \mathrm{U}$ is stored. Tube vaults are vertical pipes and tubes embedded in concrete that are ventilated to an off-gas system and are secured at their top openings. There are a total of 94 tube vaults (shown in Fig. 2) of two basic designs. Most (68) are pipes and tubes individually embedded in hexagonal concrete logs arranged to form an array that extends from one corner of a cell floor (Cell 4) through the cell ceiling, where they are anchored by concrete to a former equipment hatch. The remaining 26 vaults exist in three groups embedded in concrete walls that separate adjacent cells. ${ }^{3}$

\footnotetext{
* Separated ${ }^{233} \mathrm{U}$ is ${ }^{233} \mathrm{U}$ that has been separated from thorium target material and from fission products generated during ${ }^{233} \mathrm{U}$ production.
} 


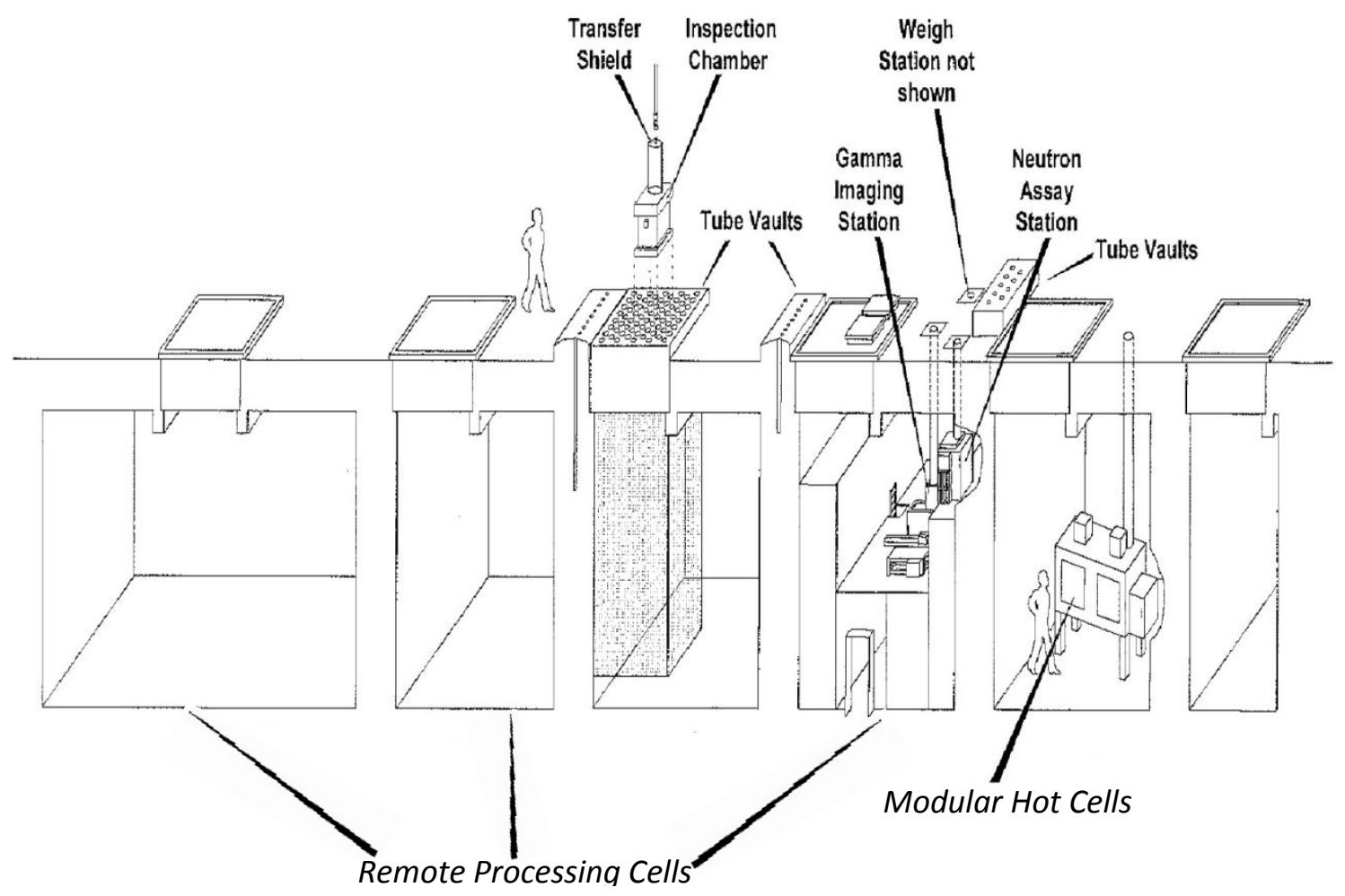

Fig. 2. Cutaway drawing of cells, tube vaults, and some of the equipment used in a recent inspection activity

Uranium-233 stored in Building 3019 is packaged in a variety of cans. Some of the more common configurations for materials packaged at Building 3019 are shown in Fig. 3.

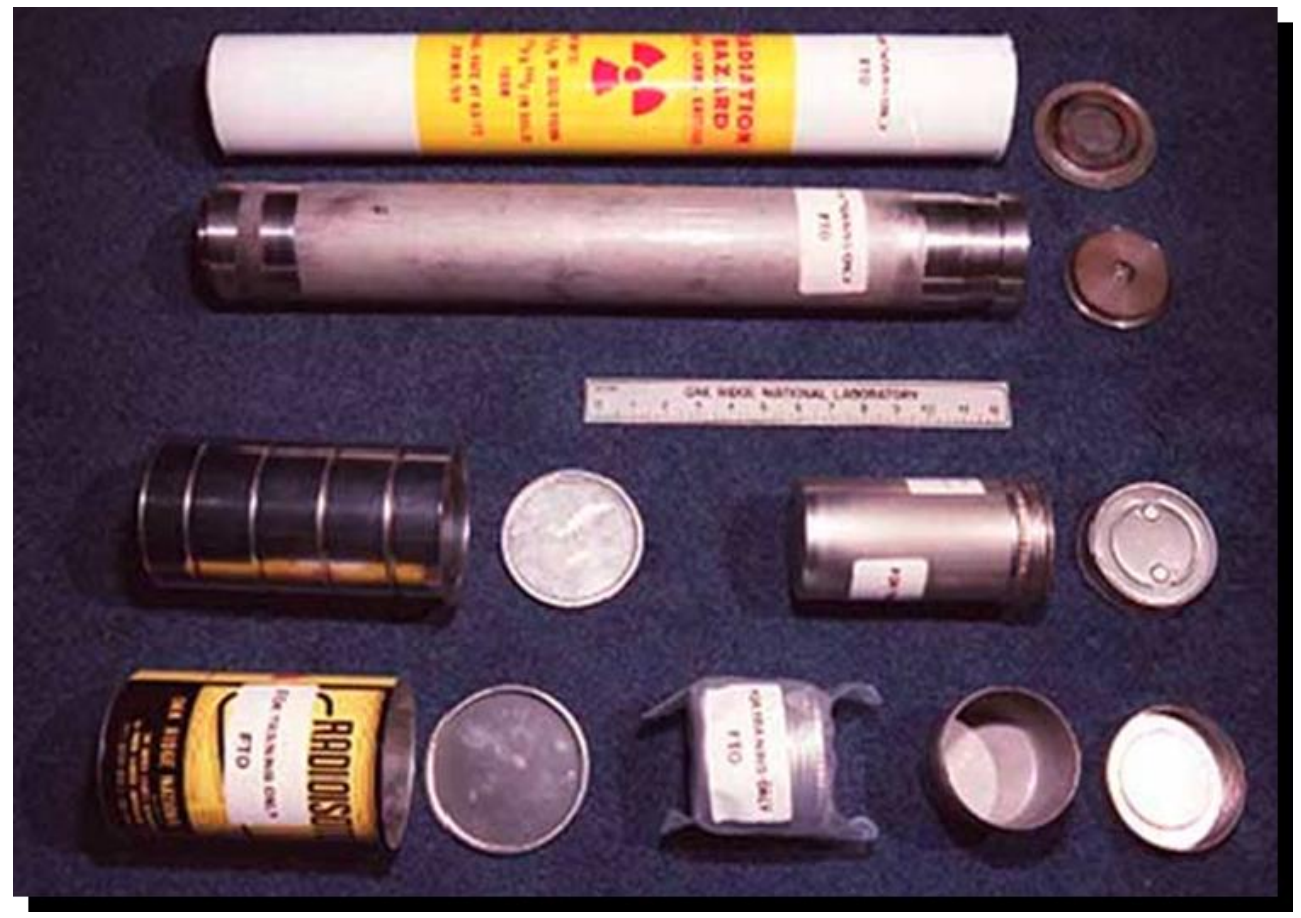

Fig. 3. Selected package configurations for ${ }^{233} \mathrm{U}$ stored at ORNL 
The purest of these materials was further purified in ${ }^{233} U$ to levels not achievable solely in a reactor. Further purification typically was achieved by electromagnetic isotopic separation (EMIS) or by chemical separation of protactinium-233, a precursor of ${ }^{233} \mathrm{U}$, which exists briefly (with a 27 day half-life) after neutron capture by natural thorium. No similarly pure materials will be produced in the future, as these and other separated ${ }^{233} \mathrm{U}$ stored at ORNL were produced and purified in the 1960s in facilities that have since been shut down. It is highly unlikely that such facilities will be restarted because of the high cost of returning them to operation.

Since it is not found in nature, ${ }^{23} \mathrm{U}$ at high isotopic purity is useful as a spike in isotope dilution mass spectrometry (IDMS) measurements for very precise quantitative determinations of uranium-bearing materials' isotopic content and uranium concentrations ${ }^{4}$ Currently, stored ${ }^{233} \mathrm{U}$ is scheduled to be down-blended with depleted uranium beginning in 2015 for safer, more cost-effective storage-by substantially decreasing the likelihood of nuclear criticality ${ }^{5}$ and by essentially eliminating its usefulness for weapons purposes. Ultimately, this material will be disposed. If this highisotopic-purity ${ }^{233} \mathrm{U}$ is compromised by mixing with depleted uranium (composed of naturally occurring uranium isotopes), its potential value as a CRM for use in uranium analysis will be destroyed permanently.

A window of opportunity for "rescuing" selected ${ }^{233} \mathrm{U}$ items from down-blending is being provided in 2013 and 2014 by the Department of Energy (DOE) in conjunction with its ${ }^{23} \mathrm{U}$ Disposition and Building 3019A Shutdown Project. Efforts to take advantage of this window for rescuing high-purity ${ }^{233} \mathrm{U}$ are described in the following sections. 


\section{STUDY OF CURRENT ${ }^{233} U$ SUPPLY AND FUTURE NEEDS}

The Next Generation Safeguards Initiative of the Office of Nonproliferation and International Security (NIS), National Nuclear Security Administration (NNSA), has funded a feasibility study for preserving surplus high-purity ${ }^{233} U{ }^{6}$ There is a historical and continuing need for this crucial isotope in analyzing uranium-containing samples derived from international safeguards and security activities. This study was commissioned to provide justification for preserving surplus materials-before they are disposed (as currently planned)—so they can replace existing, but depleting, supplies of ${ }^{233} \mathrm{U}$ CRM.

The study involved the following activities:

1. Draft a short questionnaire for identifying reference material supplies and anticipated needs.

2. Canvass domestic analytical users for the current state of their ${ }^{233} U \mathrm{CRM}$ supplies and their projected needs for supporting measurements in the foreseeable future.

3. Determine gaps between current supplies and projected needs.

4. Identify candidate ${ }^{233} U$ materials currently stored at ORNL to fill the gaps.

5. Identify distribution points for CRM and candidate locations for storing other retained batches of high-purity ${ }^{233} U$ identified for preservation.

6. Perform initial planning of the rescue and preservation process:

a. Identify major tasks that must be performed.

b. Develop a preliminary schedule of major tasks.

c. Provide a rough, order-of-magnitude estimate of cost for the planned preservation work, characterization of reference materials, and long-term ${ }^{233} \mathrm{U}$ storage.

7. Compile a report on the results of a feasibility study for preserving needed ${ }^{233} U$ materials.

The study canvassed only potential domestic users because the schedule for obtaining feedback and planning rescue activities was compressed to meet deadlines for requesting funds to preserve valued materials in the window of time available before down blending. Although only domestic users were surveyed in this study, the potential for international needs was considered by extension.

For the study, more than 50 individuals representing eight DOE/NNSA sites, three universities, and DOE-Headquarters were contacted by e-mail. This e-mail included four basic questions regarding ${ }^{233} \mathrm{U}$ :

1. How much ${ }^{233} \mathrm{U}$ do you have on hand or in storage for your use?

2. About how much ${ }^{233} \mathrm{U}$ do you use in a typical year? In a heavy-use year?

3. Do you expect your annual use of ${ }^{233} \mathrm{U}$ in future years to increase or decrease? If so, by how much?

4. What isotopic purity of ${ }^{233} U$ do you need for your use? If you need ${ }^{233} U$ at different purities, indicate needed purities and the amount of each you expect to use annually.

Replies were received by e-mail or by phone interview from six DOE/ NNSA sites (representing at least ten analytical laboratories at those sites), the National Institute of 
Standards and Technology, and one university. Only one of the ten (or more) DOE/NNSA analytical laboratories expressed no current or future need for ${ }^{233} \mathrm{U} C R M$. Preliminary indications of respondents needing ${ }^{233} \mathrm{U}$ CRM are itemized here:

- Collectively, the responding sites currently have a total of $24.6 \mathrm{~g}$ of ${ }^{233} \mathrm{U} C R M$ on hand. The vast majority of this material is located at one site, with tens of milligrams typically on hand at the other sites.

- In total, the sites consume a little more than $168 \mathrm{mg}{ }^{233} \mathrm{U}$ during a typical year and a little more than $280 \mathrm{mg}^{233} \mathrm{U}$ during a heavy-use year. Most of the ${ }^{233} \mathrm{U}$ use is at a single site (not the same site as the largest holding), but consumption is more evenly distributed among users than are the holdings themselves. These consumption rates are considered conservative (i.e., low, even for heavy use) in that laboratories are, by necessity, conserving their high-purity ${ }^{233} \mathrm{U}$ since they anticipate no future availability based on current difficulties in acquiring replacement ${ }^{233} \mathrm{U}$ CRM supplies.

- Four of the responding sites anticipate notable increases in their annual rates of CRM consumption. Three of the sites anticipate future use at their current rates.

- Collectively, the domestic sites anticipate future use at a rate of at least $1.4 \mathrm{~g}$ of ${ }^{233} \mathrm{U}$ per year. This conclusion is a compilation of respondents' projections that, for the most part, were given as rough order-of-magnitude estimates. One site indicated a future need for $\sim 1$ gram ${ }^{233} \mathrm{U}$ per year, while the balance of sites indicated needs that ranged from microgram to "at least hundreds of milligrams" quantities. (The collective future use rate of at least $1.4 \mathrm{~g}^{233} \mathrm{U}$ per year considered the plural version of order-of-magnitude projections to be at least $50 \%$ greater than the value itself [e.g., "10s" was considered to be at least 15 , and "100s" was considered to be at least 150.] This yielded a numerical total just over $1.4 \mathrm{~g}$. Since the qualifier "at least" preceded many of the projections, including some of the larger ones, this qualifier was included with the compiled value.)

- Needed ${ }^{233} \mathrm{U}$ purities for over half of the analytical laboratories were expressed as $99.99 \%$ or better. Other laboratories considered $>99.9 \%,>99.5 \%$ or $>99 \%$ to be acceptable for use, but they typically cited selected applicability for using lower purity standards (e.g., for analyzing higher concentrations of uranium or arriving at lower accuracy analyses). The lower purity standards also required trade-offs in higher consumption rates of CRM.

The results of the survey were used to determine the gap between current supplies and future needs. 


\section{GAP BETWEEN ${ }^{233} \mathrm{U}$ SUPPLIES AND NEEDS}

A summary of survey results for domestic laboratories reveals the following:

- The current inventory of ${ }^{233} \mathrm{U}$ CRM at responding laboratories is $24.6 \mathrm{~g}$.

- The current annual consumption rate is $168 \mathrm{mg}$ (typical) to $280 \mathrm{mg}$ (heavy use).

- Overall, the annual consumption rate is expected to increase to $>1.4 \mathrm{~g}$.

- Needed ${ }^{233} \mathrm{U}$ purities are at least $99 \%$, but $99.9 \%$ or higher are needed for analyzing trace concentrations if no sacrifice in accuracy is to be tolerated.

At current consumption rates, the $24.6 \mathrm{~g}$ of ${ }^{233} \mathrm{U}$ CRM currently available systemwide should last between 88 and 146 years. However, it is significant that the current consumption rate is biased low-based on a comment from some responding laboratories-since most laboratories, by necessity, conserve their high-purity ${ }^{233} \mathrm{U}$ for use in only the most critical work, assuming that there will be no future source for the isotope. This conservative use means that only a select few projects benefit from the most accurate numbers possible. Other sample preparations involve more dilutions (to approach a desired $1: 1$ ratio of ${ }^{23} \mathrm{U}$ to the main uranium isotope in the sample), which add to total uncertainties in the final results. Furthermore, it is likely that most of the increased future consumption may reflect abandoning the conservatism exercised thus far. Considering that domestic consumption rates projected by the respondents total at least $1.4 \mathrm{~g}{ }^{233} \mathrm{U}$ per year, the $24.6 \mathrm{~g}$ currently on hand in laboratories may be expected to last only up to 17 years.

The respondents were asked to project their needs 30 years into the future. Admittedly, this projection window was selected arbitrarily; and it was challenged by one respondent who suggested that maintaining a 200-year supply should be considered. Although a 200-year supply sounds excessive and is an impractical period over which to extrapolate projections, this comment did prompt reconsidering the period to be covered by the projected supply - especially since there likely will be no other source of this material in the future. Therefore, a projection for a 50-year supply was considered reasonable by the authors and the sponsor. At the projected consumption rate $(>1.4$ $\mathrm{g} / \mathrm{year}$ ), there is a domestic need for more than $70 \mathrm{~g}$ of ${ }^{233} \mathrm{U}$ CRM over the next 50 years.

That projection reflects only domestic (United States) use-although this use includes some work for the international safeguards community. The United States has a vested interest in the analytical capability of foreign laboratories since many of the laboratories participate in analytical services that support International Atomic Energy Agency efforts in documenting treaty requirements and safeguarding nuclear material. Therefore, a worldwide projection of need is warranted. Such a projection could be addressed by considering domestic projection to represent one of several regional centers for worldwide analysis of nuclear materials for safeguards - that is, to address monitoring of existing facilities that must be maintained, or to address monitoring of a substantial number of anticipated new facilities. If there are similar regional centers, with each dedicated to serving one of the continents (although it is recognized that this likely would not to be the basis for delineating analytical center locations), then there could be another five analytical centers (one each for Africa, Asia, Australia, Europe, and South America). Assuming that each center would consume similar amounts of ${ }^{233} \mathrm{U}$, a six-fold 
multiplier should be applied to the domestic projection. The total need according to this worldwide projection, then, is more than $420 \mathrm{~g}$ of ${ }^{233} \mathrm{U}$ CRM over the next 50 years.

Another consideration for ${ }^{233} U$ was to add some quantity to serve as a strategic reserve to address future applications that are not yet developed or even envisioned. Such a reserve cannot be estimated with any certainty, but retaining a quantity for the strategic reserve that is similar to the projected need for CRM is considered reasonable. Therefore, a total of $850 \mathrm{~g}$ of ${ }^{233} \mathrm{U}$ is considered a reasonable minimum target quantity for preservation. 


\section{CANDIDATE ${ }^{233} \mathrm{U}$ MATERIALS}

Uranium-233 stored at ORNL covers a wide range of isotopic purities. Materials currently being considered for preservation for use in IDMS are the purest of the ${ }^{233} \mathrm{U}$ in storage and are found in 18 individual items. ${ }^{7}$ These items are listed in summary formarranged by ${ }^{233} \mathrm{U}$ isotopic purity-in Table 1 . After these items, ${ }^{233} \mathrm{U}$ purity levels drop by almost a full percentage point, to $98.55 \%{ }^{233} \mathrm{U}$, with much diminished value.

Table 1. Summary list of candidate ${ }^{233} \mathrm{U}$ materials

\begin{tabular}{|c|c|c|}
\hline Item & ${ }^{233} \mathbf{U}(\mathbf{g})$ & ${ }^{233} \mathbf{U}$ purity (\%)* \\
\hline BA-35-1 & 4 & 99.996 \\
\hline UTHX001 & 125 & 99.98 \\
\hline 6 Items & 239 & 99.8 \\
\hline 10 Items & 591 & $99.4-99.5$ \\
\hline $\mathbf{1 8}$ Items & 959 & \\
\hline
\end{tabular}

* Purities indicated are based on existing records and need to be verified by analysis.

It is recognized that the bulk of the items in Table 1 do not meet the preferred purity (i.e., $>99.9 \%$ ) indicated by most of the respondents for IDMS. However, these moderategrade, but still high-isotopic-purity, ${ }^{233} \mathrm{U}$ materials are included in the list for the following reasons:

- They are useful for analyzing more concentrated uranium samples.

- They are useful for analyzing lower-concentration uranium samples with some sacrifice in accuracy.

- They are of sufficient purity to meet the strategic reserve needs.

- They are next in line from an isotopic purity perspective and, if required, can most readily be enriched in ${ }^{233} \mathrm{U}$ at low (gram-level) throughputs by engineeringscale EMIS. ${ }^{8}$ (Note that engineering-scale EMIS will require an investment of several million dollars to establish a capability for enriching multi-gram quantities of ${ }^{233} \mathrm{U}$ annually.)

The possibility of enriching the ${ }^{233} \mathrm{U}$ of lower purity in the list makes prompt certification-sequential to rescue activities - of all of the less pure items superfluous and unwise from a cost-effectiveness perspective, especially since the cost of certification can approach $\$ 1$ million for a given batch. Hence, some rescued batches will be qualified only by screening analysis to ensure that their isotopic purity warrants their preservation as candidate CRM. However, at least one batch of lower-purity ${ }^{233} \mathrm{U}$ in the list (which is useful for analyzing more concentrated uranium samples) will be certified in order to reserve the highest purity ${ }^{233} \mathrm{U}$ for uses in which its precision and sensitivity are needed.

As described previously, candidate materials are stacked in vertical tube vaults that are accessed from openings at their tops. Materials of interest for CRM were stored in a select few tube vaults (see Table 2, Column 4) in an effort to segregate them from less pure materials as part of a 2-year inspection program completed in 2003. However, this segregation turned out to provide a less-than-ideal configuration from the standpoint of aggregating items of like isotopic purity. That is, their arrangement in any given vault 
does not facilitate accessing materials in an order from most pure to less pure for candidate CRM.

In addition, accessing cans of special nuclear material (SNM) that are located under other cans of SNM (considered overburden; see Table 2, Column 5) is made more difficult by limitations on moving cans. Access requires placing overburden materialswhich also may include less-pure candidate CRM-one can at a time either in another tube vault (as available vault space allows) or in a shipping container (if floor space around the tube vault access area allows). Furthermore, all SNM storage configurations in tube vaults are evaluated as part of the material storage criticality analysis. If SNM is placed on top of other SNM already stored in another tube vault, that new configuration also must be evaluated. If removed overburden is to be returned to the original tube vault (with pure items left out of the mix), the new stacking arrangement must be evaluated as well before the material is restored.

Table 2. Candidate CRM in order of ${ }^{233} \mathrm{U}$ purity

\begin{tabular}{|c|c|c|c|c|c|}
\hline Item I.D. & ${ }^{233} \mathrm{U}$ purity & $\begin{array}{c}{ }^{233} U \text { content } \\
\text { (g) }\end{array}$ & Vault * & $\begin{array}{c}\text { Position } \\
\text { (overburden) }\end{array}$ & $\begin{array}{c}\text { Process } \\
\text { group }\end{array}$ \\
\hline BA-35-1 & 0.99996 & 4 & 1 & 13 & ** \\
\hline UTHX001 & 0.9998 & 125 & 1 & 1 & $\mathrm{a}$ \\
\hline $\mathrm{RCP}-16^{\dagger}$ & $0.999^{\dagger}$ & 16 & $\overline{L a b}$ & $\mathrm{~N} / \mathrm{A}$ & $\mathrm{b}$ \\
\hline KZA-G1B & 0.9980 & 63.80 & 3 & 2 & $b$ \\
\hline KZA-G1B & 0.9980 & 19.89 & 3 & 1 & $\mathrm{~b}$ \\
\hline CZD-G(CY) & 0.9976 & 13.97 & 2 & 17 & $\mathrm{c}$ \\
\hline TAR-LB1 & 0.9976 & 77 & 1 & 3 & C \\
\hline JSG-3 & 0.9976 & 48 & 1 & 5 & C \\
\hline SNM-9514 $^{\dagger}$ & $0.9965^{\top}$ & 13.0 & 2 & 14 & $\bar{d}$ \\
\hline SNM-4031 & 0.9950 & 32.25 & 2 & 20 & $d$ \\
\hline KZA-G1B & 0.9950 & 157.68 & 3 & 3 & $d$ \\
\hline PZA-126 & 0.99496 & 282.355 & 2 & 21 & $e \& f^{\diamond}$ \\
\hline OX-343 & 0.9946 & 3 & 1 & 8 & $g$ \\
\hline JSG-2 & 0.9946 & 6.8597 & 1 & 17 & $g$ \\
\hline AUA-94B & 0.9946 & 0.099 & 1 & 16 & $g$ \\
\hline SR2R & 0.99438 & 5.051 & 1 & 9 & $g$ \\
\hline CZD-G(CZ) & 0.99438 & 75 & 2 & 18 & $g$ \\
\hline CZD-G(CZ) & 0.994 & 15.5 & 2 & 18 & $g$ \\
\hline
\end{tabular}

* Vault designations are arbitrary (i.e, they do not refer to any real vault names) and are provided merely for illustrative purposes. Lab is another room in the facility (not a tube vault).

** Owing to its small size, BA-35-1 will not be processed for certification. It will be held in reserve.

† Items RCP-16 and SNM-9514 were grouped with their respective batches since their purities were based on calculations (i.e., isotope quantity/element quantity from accountability or storage records, rather than analytical records) and must be verified.

$\diamond \mathrm{PZA}-126$ may not require splitting into separate processing batches depending upon quantity restrictions for the facility in which work is conducted.

Handling candidate CRM in the order from most pure to least pure will help preserve isotopic purity during material handling, since it will minimize the possibility of contaminating purer materials with less pure ones. Therefore, material shuffling will be necessary to access materials of interest and, in some cases, may require retention in the handling laboratory to avoid new accessibility problems (if new overburden were to 
be stacked on top of them) and the costs of addressing them. Table 2 provides a list of candidate $\mathrm{CRM}$ in the preferred order of handling based on ${ }^{233} \mathrm{U}$ isotopic purity. 


\section{$5 \quad$ PLANNED ${ }^{233}$ U RESCUE ACTIVITIES}

The rescue of high-purity ${ }^{233} \mathrm{U}$ involves extensive preparations, coupled with wellcoordinated interactions with the storage facility operators, and continual activities related to qualifying rescued material. Preparations include modifying or developing work control documents and physical preparations in the laboratory. Work control documents include documented safety analysis, supporting documents, procedures, and safety permits. Physical preparations include preparing space for new material-handling equipment, procuring equipment (e.g., glove boxes, shipping drums) needed for handling ${ }^{23} \mathrm{U}$, refurbishing analytical equipment for qualifying candidate CRM, and qualifying the equipment to perform as intended during the project. Once everything is in place and operational, an evaluation of readiness will be conducted by independent reviewers to verify that the equipment, work controls, and personnel are ready for radiological operations.

Once approval is granted to operate, based on a favorable outcome of the readiness evaluation, rescue activities can commence. They will entail retrieving and handling materials in the order delineated in Table 2 according to process group (right column of Table 2). Rescue activities will involve the following for each candidate item or group of items of ${ }^{233} \mathrm{U}$ retrieved from storage (items are considered only as candidates for CRM until consensus analysis proves their quality as CRM):

1. Coordinate with ORNL storage facility operations to retrieve a specific can or cans containing ${ }^{233} \mathrm{U}$ from a tube vault.

2. Retrieve candidate CRM items listed in Table 2 from the ORNL storage facility.

(This activity will be performed primarily by storage facility personnel.)

a. Ideally, retrieve them in order of the seven groups defined in the right column of the table, which effectively categorizes them by isotopic purity.

b. Overpack the item(s) for on-site shipment.

c. Ship items to a laboratory prepared for handling and qualifying rescued materials.

3. Receive the rescued item at the prepared laboratory.

a. Add it to the material-handling glovebox.

b. Perform any needed initial processing (stabilize the items as needed, e.g., by baking out metal fines and foils to an oxide).

c. Acquire and analyze samples from each item individually within a group to allow confirmation (or rejection) of isotopic purity for each item on an individual basis. These are qualifying samples to use in screening items to ensure they meet the expected level of isotopic purity.

4. Prepare bulk material for shipment.

a. For the process groups to be certified in conjunction with preservation activities, do the following:

i. Sample the materials and package sample aliquots for "round-robin" analysis among the DOE/NNSA Network of Analytical Labs (NWAL).

ii. Package the bulk material in batches for distribution among the NWAL.

iii. Distribute the material and samples as deemed appropriate by the DOE Supervisory Physical Scientist for Mass Spectrometry.

b. For batches that are only to be qualified (screened for isotopic purity) in conjunction with preservation activities, package the bulk material in from one to a few packages for future handling, possible enrichment, and certification. 
(The purpose of limiting the number of packages within a group is to avoid security measures [safeguards] and safety measures [i.e., protection from inhalation hazards] necessary for handling larger quantities of this fissile material. These security and safety measures depend on the chemical form and presence of other isotopes, notably ${ }^{232} U$, respectively.)

5. Ship bulk material to destination labs or to a yet-to-be-designated storage location.

Careful coordination with ORNL storage facility operations is vital since all work at Building 3019 (a Hazard Category 2 nuclear facility) must be carefully planned, especially operations involving the movement of nuclear materials. In addition, facility personnel will be conducting other storage and retrieval operations during the same period as they accommodate direct transfers of multiple kilograms of ${ }^{233} \mathrm{U}$ to other sites.

Items currently are stored at ORNL in a stacked configuration and are retrieved from tube vaults accessed from the top. The listed activities reflect actions taken for each item under the simplest of cases-when the next item available (on top of a stack of stored items) is the next item of interest for preservation as candidate CRM.

To avoid cross-contamination from less pure batches, and to preserve the isotopic purity of rescued ${ }^{233} \mathrm{U}$, materials will be processed in order of purity, with the purest materials processed first. These activities can be complicated by one of two general situations. These situations arise since the items are stacked in top-loaded tube vaults so that the top item in the stack must be retrieved and dispensed with before any below it can be handled. These situations include the following:

- The next item available is not the next item of interest but is of eventual interest for candidate CRM rescue. In this case, the retrieved item will be overpacked in a shipping drum, transferred to an interim storage facility on the ORNL site, and retained (in its shipping drum) until its handling/processing time. There is very limited capacity for this option, so alternatively (and if storage facility operations can accommodate it), the retrieved item may be re-stored in another tube vault for later retrieval when its companion material is accessed.

- The next item available is not the next item of interest and also is not a candidate CRM item. In this case, one of two overall scenarios may arise:

- The non-candidate item will be retrieved and dispensed with as part of other direct programmatic transfers or down-blend activities.

- The non-candidate item will be stored in another tube vault for later retrieval as part of other direct programmatic transfers or as part of downblending of the remaining ${ }^{233} \mathrm{U}$.

In either case, removal of the "overburden" to the next item of interest must be coordinated with storage facility operations.

Another complication may arise that is unrelated to the stacked configuration of stored items. A rescued item may be found to be of significantly poorer isotopic quality than anticipated, based on a screening analysis. In this case, the poorer quality material will be returned to the storage facility for eventual down-blending. Also in this case, a substitute item may be identified for preservation to meet anticipated needs. 
It is anticipated that all identified complications can be overcome by careful coordination with key participants-program managers and the storage facility management. 


\section{RECOMMENDED PATH FORWARD}

\subsection{WORK TO BE CONDUCTED}

The work of preserving candidate CRM items can be considered in three phases: preparations, handling preserved materials, and cleanup. Preparations basically will be completed during the first year of the project, and they will involve activities described at the beginning of the previous section. These activities include obtaining an alpha glove box, i.e., a glove box suitable for handling alpha-emitting material in a Hazard Category 2 nuclear facility. (A second alpha glove box will be needed, but it will come from existing equipment.)

The material-handling phase will involve the major steps delineated in the previous section. Table 2 identifies seven groups (a through $\mathrm{g}$ ) for handling in order of isotopic purity. The utmost care must be afforded to prevent contaminating or crosscontaminating these pure batches of ${ }^{233} \mathrm{U}$.

Cleanup will involve the following:

1. wiping down the interior of, and equipment within, material handling boxes

2. removing equipment and strippable coatings from the boxes and packaging them for disposal

3. characterizing and documenting waste to be disposed of

4. disposing of waste to a repository

\subsection{SCHEDULING}

The imperative for preserving pure ${ }^{233} \mathrm{U}$ items at this time is the planned down-blend of this valuable material as part of the ${ }^{233} \mathrm{U}$ Disposition and Building 3019A Shutdown Project. Down-blend operations currently are scheduled to be conducted during the fiscal years 2015 through 2017. As part of the preparations for down-blend operations, the Federal Program Director (FPD) for the ${ }^{233} \mathrm{U}$ Disposition and Building 3019A Shutdown Project is accommodating direct transfers of materials for programmatic use, including the high-purity ${ }^{233} \mathrm{U}$ cited in this report. Direct programmatic transfers are slated for the FY 2012-2013 timeframe, which represents an aggressive schedule of operations in light of parallel efforts that must be undertaken in preparing for actual down-blend operations. Also, the somewhat scattered distribution of very pure ${ }^{233} \mathrm{U}$ items in storage places an extra burden on operations if materials are to be retrieved for preservation in an order according to isotopic purity. (The distribution is depicted in Table 2, columns 4 and 5 , indicating a vault [arbitrarily designated] and position [overburden, or indication of the number of items stored on top of the listed item].) This aggressive schedule and the scattered distribution of materials of interest as CRM have prompted the FPD to consider a more protracted schedule for rescuing candidate CRM.

A more protracted rescue schedule also is advantageous to staff performing preservation activities (i.e., after candidate items are received from Building 3019A). Preservation work involves chemical analysts who routinely handle samples and CRM for which preservation of purity is of utmost importance for valid results. These analysts already have essentially full workloads, and preservation activities must be conducted during occasional slack times or on overtime bases. Accommodating preservation work 
with the existing workload becomes much easier if these activities are spread over a longer period of time. At best, the groups of candidate CRM can be accommodated at a rate of up to one group every 2 months. At this rate, and if Building 3019A operations can accommodate material retrievals accordingly, up to six of the seven process groups can be handled in the second year. The seventh group and any required re-analysis must be completed in the third year of the project. Hence, the willingness and proclivity of the FPD to consider a more protracted schedule aligns better with the analysts' abilities to accommodate the work than would a more aggressive schedule.

\subsection{LOCATIONS FOR RETAINING PRESERVED ${ }^{233} \mathrm{U}$}

As mentioned in the previous section, the location for retaining preserved materials is an outstanding issue. Retention of preserved materials currently is planned in one of two categories of locations. The first is distributed, in-process retention of CRM at NWAL sites to allow these laboratories to meet their commitments for uranium analysis. Inprocess retention applies (contingent upon confirming isotopic purity) to the large (125 gram) item of very pure material designated as UTHX001. It also applies to a lowerpurity CRM, such as Process Group ' $\mathrm{g}$,' intended for use in analyzing higherconcentration materials to preserve the most pure, large batch of CRM identified in Table 2, UTHX001, for analysis of trace samples.

The second type of location applies to the storage of candidate CRM not currently needed in the lab but useful in the foreseeable future. This location has not yet been designated, and resolving it requires working with another DOE-managed program, the Nuclear Materials Information Program (NMIP). NMIP is preserving other nuclear and radiological materials (e.g., most notably, highly enriched uranium and weapons-grade plutonium) required in safeguards and forensics endeavors. In October 2010, NMIP identified Los Alamos National Laboratory and the Y-12 Nuclear Security Complex as the designated archive storage facilities for plutonium-based archives and uraniumbased archives, respectively. ${ }^{9}$ However, the uranium-based archives, in this context, are limited to storing naturally occurring uranium isotopes, which ${ }^{233} \mathrm{U}$ is not. Therefore, this preservation activity is working with NMIP management to identify an appropriate location for storing preserved ${ }^{233} U$ that is not needed immediately for analytical purposes. It also is notable that other items of ${ }^{233} \mathrm{U}$ stored at ORNL are being readied for transfer and storage at another site in the DOE/NNSA complex. This other storage activity provides a model and potential location for storing ultra-pure ${ }^{233} \mathrm{U}$ materials preserved for, but not needed immediately in IDMS laboratories. ${ }^{10}$ 


\section{COST ESTIMATE FOR CANDIDATE ${ }^{233} \mathrm{U}$ CRM RESCUE}

\subsection{COSTS OF PRESERVATION ACTIVITIES}

The costs of major activities necessary for preserving candidate CRM items are summarized in Table 3. These costs include preparations, material-handling activities, and cleanup. The costs of material-handling activities are based on a schedule of processing one batch every 2 months if Building 3019A operations can accommodate requisite material retrievals accordingly. This would allow six of the seven batches to be processed in 2013 with handling the final batch and cleanup completed in 2014.

Table 3. Annualized estimate of costs for recuing candidate ${ }^{233} U$ CRM

\begin{tabular}{|c|c|}
\hline Activity & Estimated cost $(\$ k)$ \\
\hline \multicolumn{2}{|l|}{ FY 2012} \\
\hline Develop or Modify Work Controls & 373 \\
\hline \multicolumn{2}{|l|}{ Laboratory Preparations } \\
\hline $\begin{array}{l}\text { Prepare laboratory spaces for material handling and analysis } \\
\text { equipment }\end{array}$ & 275 \\
\hline $\begin{array}{l}\text { Procure, install, and qualify equipment needed for material } \\
\text { certification }\end{array}$ & 216 \\
\hline Non-Capital Equipment & 157 \\
\hline Conduct Readiness Assessment & 107 \\
\hline Capital Equipment & $100^{*}$ \\
\hline Total FY 2012 Cost & 1,228 \\
\hline \multicolumn{2}{|l|}{ FY 2013} \\
\hline Preserve six out of seven batches of candidate CRM & 1,375 \\
\hline Total FY 2013 Cost & 1,375 \\
\hline \multicolumn{2}{|l|}{$\begin{array}{ll}\text { FY } 2014 \\
\end{array}$} \\
\hline $\begin{array}{l}\text { Preserve seventh batch of candidate CRM, complete } \\
\text { analyses, and distribute samples }\end{array}$ & 470 \\
\hline Clean out material handling equipment & 460 \\
\hline Characterize and dispose of waste & 100 \\
\hline Total FY 2014 Cost & 1,030 \\
\hline
\end{tabular}

* The threshold for defining capital equipment (currently $\$ 50 \mathrm{~K}$ ) is expected to increase to $\$ 500 \mathrm{~K}$ in the near future and may render this a non-capital item, which would increase this amount by $\sim 15 \%$ as different overhead charges are applied.

Note that the ${ }^{233} \mathrm{U}$ preservation project is not paying for costs of material retrievals from storage, per se; such costs are paid by the ${ }^{233} \mathrm{U}$ Disposition and Building 3019A Shutdown Project as part of their material disposition mission. Hence, the ${ }^{233} \mathrm{U}$ preservation project must coordinate its work with that of other activities associated with the ${ }^{233} \mathrm{U}$ Disposition and Building 3019A Shutdown Project. In broad terms, these activities include direct transfer of multi-kilogram batches of ${ }^{233} \mathrm{U}$ for other programs and physical preparations for down-blend of ${ }^{233} \mathrm{U}$ remaining after direct transfers. Notably, much larger quantities are involved in these direct transfers to other programs, giving them a higher scheduling priority than the preservation project in making progress toward fulfilling the ${ }^{233} \mathrm{U}$ disposition mission. 
This means that materials may not be retrieved for preservation to allow the scheduled rate of material handling mentioned (i.e., baseline processing rate: one batch every 2 months) that would leave only one batch to be processed for preservation in 2014. One additional batch can be processed in 2014 with minimal impact (since that batch extends into 2014 as originally planned) and without preservation activities extending into the following fiscal year. However, if material retrieval should require that more than two batches be processed in FY 2014, then project completion would extend into FY 2015 and more substantial impacts to project costs would occur. If the delay in project completion is limited to sometime in FY 2015, then the total estimated incremental increase in ${ }^{233} \mathrm{U}$ preservation project cost is

First additional batch in 2014: $\quad$ \$10K (project completion still in FY 2014)

Second additional batch in 2014: \$50K (project completion in FY 2015)

Third additional batch in 2014: $\quad \$ 40 \mathrm{~K}$

Fourth additional batch in 2014: $\quad$ \$35K

Fifth additional batch in 2014: $\quad$ \$30K

Sixth additional batch in 2014: $\quad$ \$30K

Note that these are incremental costs; so, for example, if four batches were delayed until 2014 (i.e., five total batches processed in 2014), then the total added cost to the preservation project would be the sum of these increments, or an estimated additional $\$ 135 \mathrm{~K}$, due mainly to additional project controls and escalation.

Although it may be likely that Building 3019 operating schedules will cause a delay in retrieving one batch of candidate ${ }^{233} \mathrm{U} C R M$ (with negligible impact on both cost and schedule), delays of additional batches are considered to be less likely. They should be circumvented by frequent interaction between project and facility personnel to ensure timely retrieval of target items and by schedule flexibility on the part of staff performing preservation activities on retrieved items to accommodate material retrievals. 


\section{CONCLUSION}

As can be seen in the description of activities, preserving ${ }^{233} U$ items which are considered candidate CRM is an involved undertaking for which coordination, cooperation, and careful handling practices are key to successful execution. A close working relationship between facility and project personnel will help ensure such coordination and cooperation. Careful handling practices to ensure safe handling and to maintain material purity are inherent attributes of the nuclear facility operators who will retrieve candidate CRM items from storage and the chemical analysts who will handle the material outside of containers.

Since materials of interest will not be produced in the future, it is essential that the analytical community, and those who rely on their services, plan on and support preserving all candidate materials that will be needed (using reasonably high estimates of need) for the foreseeable future. If we underestimate the need, there likely will be no source of high-purity ${ }^{233} \mathrm{U} C R M$ to satisfy any need not accommodated by this preservation activity. 


\section{ACKNOWLEDGEMENT}

The authors wish to acknowledge the Next Generation Safeguards Initiative (NGSI), Office of Nonproliferation and International Security (NIS), National Nuclear Security Administration (NNSA), for its support of this study and its support of the coordination efforts aimed at rescuing this valuable material. 


\section{REFERENCES}

1. American Nuclear Society, Nuclear Criticality Safety in Operations with Fissionable Materials Outside Reactors, ANSI/ANS-8.1-1998; R2007 (Reaffirmed), ANS, LaGrange Park, IL, 1998.

2. R. E. Brooksbank, Sr., B. D. Patton, and A. M. Krichinsky, Historical and Programmatic Overview of Building 3019, ORNL/TM-12720, Oak Ridge National Laboratory, Oak Ridge, TN, August 1994.

3. T. B. Conley, et al., Summary Report on DNFSB 97-1 Inspections of ${ }^{233} U$ Storage at Oak Ridge National Laboratory, ORNL/TM-2004/21, Oak Ridge National Laboratory, Oak Ridge, TN, April 2004.

4. ASTM International, Standard Test Method for Determination of Uranium Content and Isotopic Composition by Isotope Dilution Mass Spectrometry, ASTM C1380-04, ASTM International, West Conshohocken, PA, 2004.

5. Technical Handbook of ${ }^{233} U$ Material Properties, Processing, and Handling Guidelines, ORNL/TM-13600, Oak Ridge National Laboratory, Oak Ridge, TN, April 1999.

6. A. M. Krichinsky, et al, Rescuing a Treasure-Uranium-233, Proceedings of the Institute of Nuclear Materials Management $52^{\text {nd }}$ Annual Meeting, Palm Desert, CA, July 17-21, 2011.

7. T. B. Conley, et al., Summary Report on DNFSB 97-1 Inspections of ${ }^{233} U$ Storage at Oak Ridge National Laboratory, ORNL/TM-2004/21, Oak Ridge National Laboratory, Oak Ridge, TN, April 2004.

8. Andre Gsponer, and Jean-Pierre Hurni, Iraq's Calutrons: Electromagnetic Isotope Separation, Beam Technology, and Nuclear Weapon Proliferation, ISRI-95-03, 19 October 1995.

9. Jamison Manternach, Director, Nuclear Materials Security Division, ACTION: Recommendation of Nuclear Materials Information Program (NMIP) Materials Archive Locations, letter via Don L. Cook, Deputy Administrator, Defense Programs, to Edward Bruce Held, Director, Office of Intelligence and Counterintelligence on November 1, 2010.

10. Jerry McKamy, Nuclear Criticality Safety Program Manager, "Preservation of Select Uranium 233 Material for Criticality Safety Experiments”, DOE/NNSA Memorandum to Dale Dunsworth, Materials Manager in the Office of Stockpile Technology, September 19, 2006. 